\title{
Pengaruh Progressive Muscle Relaxation (PMR) terhadap Penurunan Tekanan Darah pada Lansia Hipertensi di Panti Sosial Tresna Wherda Palembang Provinsi Sumatera Selatan Tahun 2018
}

\author{
Mareta Akhriansyah \\ STIK Bina Husada Palembang \\ Email : maretaakhriansyah@gmail.com
}

\begin{abstract}
Hypertensioncan we call as "silent killer" because it could be making an ice mountain fenomenal. Hypertension prevalence will increasing with getting older of that people. Identical of Hypertension is a increasing of blood pressure more than normal limit. The aim of this study was to know an influence of relationship between progresive muscle relaxationtoward decreasing blood pressure of old peoplehypertension in Nursing Home. This study used"Quasi Experimental Pre-Post Test With Control Grup"design withProgresive Muscle Relaxation (PMR) intervension, sample is taking by purposive sampling technique with 30 respondents, which they are divided into 2 group as treatment group and control group. Both of that groups are getting measurement of their blood pressure. The result showed that after Progresive Muscle Relaxation Exercise there is a decreasing systolic of blood pressure $28,7 \mathrm{mmHg}$ and decreasing dyastolic of blood pressure $18 \mathrm{mmHg}$. And finally this study having conclusion that Progresive Muscle Relaxation Exercise can make decreasing blood pressure systolic and dyastolic with certainly result $(p=0.000<\alpha=0.05)$. To increasing a healthy Old People meassurement there must be a policy development to make progressive muscle relaxation exercise will application well to Old People Hypertension
\end{abstract}

Keywords:

Old people hypertension, progressive muscle relaxation.

\section{PENDAHULUAN}

Batasan lansia yang ditetapkan oleh Organisasi Kesehatan Dunia atau World Health Organization (WHO) 2011, seseorang yang telah berusia 60 tahun atau lebih (>60 tahun). Berdasarkan defenisi secara umum, seseorang dikatakan lansia (lansia) apabila usianya 65 tahun ke atas. Iansia diseluruh dunia pada tahun 2025 diperkirakan berjumlah 1,2 milyar, di kawasan Asia Tenggara populasi lansia sebesar $8 \%$ atau sekitar 142 juta jiwa. Pada tahun 2050 diperkirakan populasi lansia meningkat 3 kali lipat dari tahun 2013. Pada tahun 2000 jumlah Lansia sekitar $5.300 .000 \quad(7,4 \%)$ dari total populasi, sedangkan pada tahun 2010 jumlah Lansia $24.000 .000(9,77 \%)$ dari total populasi, dan tahun 2020 diperkirakan jumlah Lansia mencapai $28.800 .000 \quad(11,34 \%)$ dari total populasi. Pada penelitian ini batasan lansia yang digunakan adalah sesuai dengan ketetapan WHO dan ketetapan yang berlaku di Indonesia.

Menurut BPS RI-Susenas (2013), sebaran penduduk lansia menurut provinsi, persentase penduduk lansia di atas $10 \%$ ada di provinsi D.I. Yogyakarta (13,04\%), Jawa Timur $(10,40 \%)$, Jawa Tengah (10,34\%) dan Jambi $(6,23 \%)$ (Buletin Lansia, 2013). Untuk provinsi Sumatera Selatan persentasi penduduk lansianya masih dibawah $10 \%$.

Pertumbuhan penduduk lanjut usia (lansia) diprediksi akan meningkat cepat di masa yang akan datang terutama di negara-negara berkembang. Indonesia sebagai salah satu negara berkembang juga akan mengalami ledakan jumlah penduduk lansia, kelompok umur
0-14 tahun dan 15-49 tahun berdasarkan proyeksi 2010-2035 menurun. Sedangkan kelompok umur lansia berdasarkan proyeksi 2010-2035 terus meningkat (Buletin Lansia, Kemenkes, 2012).

Dengan meningkatnya jumlah lansia pada saat ini berdampak terjadi perubahan hidup sehat atau haya hidup seseorang, sehingga berdampak pada pergeseran pola penyakit di mana beban penyakit tidak lagi didominasi oleh penyakit menular, tetapi juga penyakit tidak menular seperti hipertensi (Depkes, 2013).

Hipertensi merupakan "silent killer" sehingga menyebabkan fenomena gunung es. Prevalensi hipertensi meningkat dengan bertambahnya usia. Kondisi patologis ini jika tidak mendapatkan penanganan secara cepat dan secara dini maka akan memperberat risiko (Wahyuningsih, 2013). Hipertensi identik dengan peningkatan tekanan darah melebihi batas normal. Seseorang dikatakan hipertensi jika hasil pengukuran tekanan darah sistoliknya $>140$ $\mathrm{mmHg}$ dan diastoliknya $>90 \mathrm{mmHg}$ (Sunardi, 2012)

Berdasarkan data WHO dalam Noncommunicable Disease Country Profiles prevalensi didunia pada usia $>25$ tahun mencapai 38,4\%. Prevalensi Indonesia lebih besar jika dibandingkan dengan Banglandesh, Korea, Nepal, dan Thailand. Prevalensi hipertensi di Indonesia pada usia $>18$ tahun mencapai 25,8\%. Bangka Belitung merupakan provinsi yang menempati posisi pertama sebesar 30,9\%, Kalimantan Selatanpada posisi kedua sebesar 30,8\%, Kalimantan Timur 
$(29,6 \%)$, sedangkan di wilayah Sumatera Selatan berjumlah sebesar $26,1 \%$ (Riset Kesehatan Dasar, 2013).

Gejala hipertensi biasanya samar, nyeri kepala dan leher bagian kepala, atau gejala lain sesuai kerusakan organ seperti nokturia, gelisah, mual dan muntah serta gangguan penglihatan, juga masih banyak pasien hipertensi yang belum mendapatkan pengobatan maupun yang sudah diobati tetapi tekanan darah belum mencapai target serta adanya penyakit penyerta dan komplikasi (Sudoyo, 2006).

Semakin meningkatnya usia maka lebih beresiko terhadap peningkatan tekanan darah terutama tekanan darah sistolik sedangkan diastolik meningkat hanya sampai usia 55 tahun (Nurrahmani, 2011). Laki-laki atau perempuan sama-sama memiliki kemungkinan beresiko hipertensi. Namun, laki-laki lebih beresiko mengalami hipertensi dibandingkan perempuan saat usia $<45$ tahun tetapi pada usia $>65$ tahun perempuan lebih beresiko mengalami hipertensi (Prasetyaningrum, 2014).

Beberapa penangan dalam hipertensi yaitu penanganan farmakologis dan non farmakologis, beberapa teknik non farmakologis yaitu teknik relaksasi napas dalam, relaksasi aroma terapi mawar, terapi mandi uap, pijat refleksi kaki, hipnoterapi dan relaksasi otot progresif (Progressive Muscle Relaxation). Peneliti menggunakan penanganan pada hipertensi dengan non farmakologis yaitu dengan menggunakan teknik relaksasi otot progresif (Progressive Muscle Relaxation), beberapa kelebihan dan keistimewaan dari teknik relaksasi otot progresif ini yaitu menurunkan ketegangan otot, kecemasan, nyeri leher, sakit kepala, sakit punggung, frekuensi jantung, frekuensi pernapasan laju metabolic, menurunkan denyut nadi, menurunkan tekanan darah sistolik dan diastolik serta mengurangi stress pada lansia, menurunkan kecemasan dan depresi dengan meningkatkan control diri (sucipto, 2014).

Efek dari teknik relaksasi pada tekanan darah tinggi telah dikonfirmasi positif, lebih kurang 60-90\% klien konsultasi ke dokter keluarga yang terkait dengan stress, sejumlah besar memiliki tekanan darah tinggi. Akibat manajemen stress mempunyai posisi penting pengobatan anti-hipertensi yang efektif digunakan. Teknik relakasi yang tepat adalah relaksasi otot progresif, latihan aoutogenik, pernapasan dan visualisasi (Schwickert, 2006).

Indikasi terapi ini adalah lansia yang mengalami insomnia, stres, ansietas, depresi dan ketegangan fisik/otot-otot (Setyoadi, 2011). Berdasarkan hal tersebut menunjukkan bahwa PMR adalah salah satu terapi relaksasi yang dapat digunakan untuk mengatasi ansietas dan insomnia pada lansia.
Relaksasi otot progresif merupakan teknik yang diciptakan oleh Dr. Edmund Jacobson lima puluh tahun lalu di Amerika Serikat, adalah salah satu teknik kusus yang di desain untuk membantu meredakan ketegangan otot yang terjadi ketika sadar pertama ada harus mengetahui derajat ketegangan tersebut melalui teknik pelepasa ketegangan, akhir-akhir ini, Relaksasi otot progresif di gunakan sebagai terapi untuk membantu meredakan beberapa gejala yang berkaitan dengan stress, seperti insomnia, hipertensi, sakit kepala dan nyeri (Asmadi, 2008). Indikasi terapi ini adalah lansia yang mengalami insomnia, stres, ansietas dan depresi (Setyoadi, 2011)

Penelitian terkait yang telah dilakukan oleh Harmanto R (2010) yang berjudul Pengaruh latihan relaksasi otot progresif terhadap penurunan tekanan darah pada klien hipertensi diperoleh hasil bahwa ada penurunan tekanan darah sistolik sebesar $16,65 \mathrm{mmHg}$ dan darah diastolic mengalami penurunan $3,8 \mathrm{mmHg}$. Sejalan dengan penelitian yang dilakukan oleh Amalia (2014), mengungkapkan bahwa terapi PMR berpengaruh dalam penurunan vital sign (tekanan darah sistol, diastole dan denyut nadi).

Berdasarkan hal tersebut menunjukkan bahwa Progressive Muscle Relaxation adalah salah satu terapi relaksasi yang dapat digunakan untuk mengatasi hipertensi pada lansia. Hal tersebut di atas menjadi alasan peneliti tertarik untuk melaksanakan terapi Progressive Muscle Relaxation di Panti Sosial Tresna Wherda (PSTW).

Berdasarkan hasil studi pendahuluan peneliti yang dilaksanakan pada tanggal $26 \mathrm{Mei}$ 2018 di PSTW Warga Tama Indralaya di peroleh data jumlah lansia yang tinggal sebanyak 75 orang lansia dan di PSTW Teratai berjumlah 60 orang lansia, didapatkan hasil observasi dengan 10 lansia ditemukan bahwa terdapat 7 orang lansia (70\%) memiliki tanda-tanda mengalami keluhan nyeri kepala yang menetap, pusing, dada berdebar-debar, mengalami kelelahan fisik, saat siang hari kurang konsentrasi dan mudah tersinggung. Hal tersebut disebabkan karena lansia sering memikirkan sanak keluarga yang jauh, gelisah dan rindu dengan keluarga meskipun mereka tinggal di panti dengan temanteman sebaya, takut jika sakit tidak ada yang mengurus dan akhirnya merepotkan orang lain, mengalami ketegangan pada otot-otot ekstemitas bawah, takut tidak bisa beraktivitas dan takut menghadapi kematian.

Di Panti Sosial Tresna Wherda Warga Tama Indralaya dan Panti Sosial Tresna Wherda Teratai telah mempunyai petugas kesehatan khusus yang tinggal di panti yang melakukan pemeriksaan kesehatan rutin setiap bulannya. Berdasarkan hasil studi pendahuluan peneliti wawancara dengan petugas kesehatan yang 
melakukan pemeriksaan kesehatan di PSWT mengungkapkan bahwa banyak terdapat lansia yang mengalami hipertensi. Penyakit hipertensi merupakan penyakit kedua terbanyak pada lansia yang tinggal di PSTW. Tindakan yang dilakukan perawat adalah memberikan pendidikan kesehatan dan pemberian obat serta Vitamin. Lansia di panti tesebut sudah pernah dilakukan Terapi Aktivitas Kelompok (TAK) bermain dan kognitif. Untuk Terapi Progresive Muscle Relaxation (PMR) baik secara individu maupun secara kelompok belum pernah diberikan pada lansia, padahal terapi ini merupakan tindakan yang cukup efektif untuk lansia yang mengalami Hipertensi.

\section{METODE PENELITIAN}

Penelitian ini merupakan penelitian kuantitatif dengan menggunakan desain penelitian "Quasi Experimental Pre-Post Test With Control Grup" dengan intervensi Progresive Muscle Relaxation (PMR). Rancangan ini menggunakan kelompok kontrol (pembanding) yang memungkinkan peneliti melihat perubahanperubahan tekanan darah sebelum dan sesudah diberikan terapi PMR. Penelitian ini menggunakan dua kelompok yaitu kelompok intervensi I (kelompok yang diberi intervensi terapi PMR), kelompok II (kelompok non intervensi PMR / kelompok kontrol yang hanya mendapatkan penyuluhan tentang hipertensi). Populasi dalam penelitian ini adalah lansia hipertensi yang tinggal di Panti Sosial Tresna Werdha Warga Tama Indralaya dan Panti Sosial Tresna Werdha Teratai Palembang dengan jumlah sampel sebanyak 30 responden. Penelitian ini dilakukan pada bulan Juli 2018.

\section{HASIL DAN PEMBAHASAN}

Hasil Penelitian yang dipaparkan meliputi karakteristik dan kesetaraan lansia berdasarkan jenis kelamin dan usia, pengaruh terapi Progressive Muscle Relaxation terhadap tekanan darah lansia.

Tabel 1. Karakteristik Jenis kelamin lansia di Panti Sosial Tresna Wherda Sumatera Selatan tahun $2018(n=30)$

\begin{tabular}{cccccccc}
\hline Karakteristik & \multicolumn{2}{c}{ Kelompok Intervensi } & \multicolumn{2}{c}{ Kelompok Kontrol } & \multicolumn{2}{c}{ Total (N=84) } & \multicolumn{2}{c}{$\mathbf{P}$} \\
Value
\end{tabular}

Hasil penelitian menunjukkan bahwa lansia hampir seluruh responden adalah perempuan yaitu sebanyak $21(70 \%)$.

Tabel 2. Usia lansia di Panti Sosial Tresna Wherda Sumatera Selatan Tahun $2018(n=30)$

\begin{tabular}{cccccccc}
\hline Variabel & Kelompok terapi & $\mathbf{n}$ & Mean & SD & SE & Min-Maks & P Value \\
\hline Usia & Intervensi & 15 & 69,40 & 1,668 & 1,588 & $65-71$ & \multirow{2}{*}{$\mathbf{1 6 8}$} \\
& Kontrol & 15 & 67,07 & 1,568 & 0,441 & $64-70$ & $\mathbf{6 4 - 7 1}$ \\
& Total & $\mathbf{3 0}$ & $\mathbf{6 8 , 2 3}$ & $\mathbf{1 , 6 1 8}$ & & $\mathbf{6 4 7}$ \\
\hline
\end{tabular}

Hasil penelitian menunjukkan bahwa ratarata usia Iansia 68,23 Tahun. Hasil uji kesetaraan menunjukkan bahwa $p$ value $>0,05$ yang artinya tidak ada perbedaan yang bermakna rata-rata usia lansia pada kelompok intervensi dan kelompok control.

Tabel 3. Tekanan Darah lansia Sebelum Intervensi di Panti Sosial Tresna Wherda Sumatera Selatan tahun $2018(n=30)$

\begin{tabular}{ccccccc}
\hline Variabel & Kelompok terapi & $\mathbf{n}$ & Mean & SD & Min-Mak & P Value \\
\hline \multirow{3}{*}{ Sistolik } & Intervensi & 15 & 159,3 & 10,328 & $140-180$ & $\mathbf{0 , 7 2 6}$ \\
& Kontrol & 15 & 160,6 & 10,328 & $140-180$ & \\
& Total & $\mathbf{3 0}$ & $\mathbf{1 5 9 , 9 5}$ & & & \\
Distolik & Intervensi & 15 & 108 & 11,464 & $90-130$ & $\mathbf{0 , 6 5 2}$ \\
& Kontrol & 15 & 110 & 12,536 & $90-130$ & \\
& Total & $\mathbf{3 0}$ & $\mathbf{1 0 9}$ & & & \\
\hline
\end{tabular}

Hasil penelitian menunjukkan bahwa ratarata tekanan darah sistolik pada kedua kelompok lansia sebelum mendapatkan terapi sebesar $159,95 \mathrm{mmHg}$ masuk dalam tingkat hipertensi derajat 1. Sedangkan rata-rata tekanan darah diastolik pada kedua kelompok lansia sebelum mendapatkan terapi sebesar 109 $\mathrm{mmHg}$ masuk dalam tingkat hipertensi tingkat 2 . Maka dapat disimpulkan bahwa kedua kelompok lansia mengalami hipertensi sebelum mendapatkan terapi.. Hasil uji kesetaraan menunjukkan bahwa $p$ value $>0,05 y$ ang artinya tidak ada perbedaan yang bermakna rata-rata tekanan darah lansia pada kelompok intervensi dan kelompok kontrol. Maka dapat disimpulkan bahwa rata-rata tekanan darah lansia pada kedua kelompok tersebut setara atau homogen. 
Tabel 4. Tekanan Darah lansia Sebelum dan Sesudah Diberikan Intervensi di Panti Sosial Tresna Wherda Sumatera Selatan tahun $2018(n=30)$

\begin{tabular}{|c|c|c|c|c|c|c|}
\hline Variabel & Kelompok & Terapi & Mean & $\overline{\text { SD }}$ & $\overline{\text { SE }}$ & P Value \\
\hline \multirow{2}{*}{ Sistolik } & Intervensi & $\begin{array}{l}\text { Sebelum } \\
\text { Sesudah }\end{array}$ & $\begin{array}{l}159,3 \\
130,6\end{array}$ & $\begin{array}{l}10,328 \\
10,328\end{array}$ & $\begin{array}{l}2,667 \\
2,667\end{array}$ & 0,000 \\
\hline & Kontrol & $\begin{array}{l}\text { Sebelum } \\
\text { Sesudah }\end{array}$ & $\begin{array}{l}160,6 \\
155,3\end{array}$ & $\begin{array}{c}10,328 \\
7,432\end{array}$ & $\begin{array}{l}2,667 \\
1,919\end{array}$ & 0,120 \\
\hline \multirow{2}{*}{ Diastolik } & Intervensi & $\begin{array}{l}\text { Sebelum } \\
\text { Sesudah }\end{array}$ & $\begin{array}{c}108 \\
90\end{array}$ & $\begin{array}{l}11,464 \\
12,536\end{array}$ & $\begin{array}{l}2,960 \\
3,237\end{array}$ & 0,000 \\
\hline & Kontrol & $\begin{array}{l}\text { Sebelum } \\
\text { Sesudah }\end{array}$ & $\begin{array}{l}110 \\
107\end{array}$ & $\begin{array}{c}12,536 \\
8,837\end{array}$ & $\begin{array}{l}3,237 \\
2,282\end{array}$ & 0,217 \\
\hline
\end{tabular}

Hasil penelitian menunjukkan bahwa lansia yang mendapatkan intervensi kondisi sistolik menurun secara bermakna ( $p$ value < $0,05)$ dari $159,3 \mathrm{mmHg}$ menjadi $130,6 \mathrm{mmHg}$ masuk dalam kategori prehipertensi. Sedangkan pada kelompok kontrol tekanan darah sistolik tidak mengalami penurunan yang signifikan ( $p$ value $>0,05$ ) dari $160,6 \mathrm{mmHg}$ menjadi 155,3 dan masuk dalam hipertensi derajat 1 . Penurunan tekanan darah sistolik pada kelompok intervensi lebih besar dibandingkan dengan tekanan darah sistolik pada kelompok kontrol.
Hasil penelitian juga menunjukkan bahwa lansia yang mendapatkan intervensi kondisi diastolik menurun secara bermakna ( $p$ value < $0,05)$ dari $108 \mathrm{mmHg}$ menjadi $90 \mathrm{mmHg}$ masuk dalam kategori hipertensi derajat 1 . Sedangkan pada kelompok kontrol tekanan darah diastolik tidak mengalami penurunan yang signifikan ( $p$ value > 0,05) dari $110 \mathrm{mmHg}$ menjadi 107 $\mathrm{mmHg}$ dan masuk dalam kategori hipertensi derajat 2. Penurunan tekanan darah diastolik pada kelompok intervensi lebih besar dibandingkan dengan tekanan darah diastolic pada kelompok control.

Tabel 5. Ansietas dan Insomnia lansia Sesudah Intervensi di Panti Sosial Tresna Wherda Sumatera Selatan tahun $2018(n=30)$

\begin{tabular}{cccccc}
\hline Variabel & Kelompok terapi & $\mathbf{n}$ & Mean & SD & Min-Mak \\
\hline \multirow{3}{*}{ Sistolik } & Intervensi & 15 & 130,6 & 10,328 & $140-180$ \\
& Kontrol & 15 & 149,3 & 10,328 & $140-180$ \\
& Total & $\mathbf{3 0}$ & $\mathbf{1 3 9 , 9}$ & & $\mathbf{0 , 6 2 6}$ \\
Distolik & Intervensi & 15 & 88 & 11,464 & $90-130$ \\
& Kontrol & 15 & 107,3 & 12,536 & $90-130$ \\
& Total & $\mathbf{3 0}$ & $\mathbf{9 7 , 6}$ & & $\mathbf{0 , 4 5 2}$ \\
\hline
\end{tabular}

Hasil penelitian menunjukkan bahwa ratarata tekanan darah sistolik dan diastolik lansia pada kelompok yang mendapatkan intervensi terapi PMR mengalami penurunan lebih besar secara bermakna dibandingkan dengan kelompok kontrol. Pada alpha 0,05 terdapat perbedaan antara rata-rata tekanan sistolik pada kedua kelompok lansia tersebut bermakna ( $p$ value $<0,05)$.

\section{Pembahasan Umur}

Responden dalam penelitian ini adalah lansia yang yang mengalai hipertensi di PSTW Sumatera Selatan yang mempunyai umur antara 64 - 71 tahun. Hasil penelitian ini sejalan dengan teori yang mengatakan bahwa tekanan darah akan meningkat seiring dengan pertambahan umur, pada lansia tekanan darah sistoliknya meningkat sehubungan dengan penurunan elastisitas pembuluh darah (Perry \& Potter, 2005). Kaplan (2002) mengatakan bahwa angka kejadian hipertensi meningkat cepat pada usia 65 tahun keatas dan menurun pada usia 30 tahun ke bawah.

Peneliti berasumsi bahwa semakin bertambahnya usia maka semakin beresiko mengalami hipertensi, dikarenakan adanya perubahan struktur anatomi dan fisiologi pada sistem kardiovaskuler. Diakibatkan proses penuaan maka kemampuan jantung dalam memompa darah kurang efisien dikarenakan kaku nya katub jantung dan kurangnya elastisitas pembuluh darah.

\section{Jenis Kelamin}

Jenis kelamin responen penelitian ini sebesar $70 \%$ perempuan. Hasil penelitian ini sejalan dengan teori menurut Black \& Hawk (2005) yang mengatakan bahwa antara usia 55 - 74 tahun resiko hipertensi hampir sama, setelah usia 74 tahun wanita lebih besar resikonya. Kaplan (2002) mengatakan bahwa perempuan mempunyai toleransi yang lebih baik dari pada laki-laki terhadap hipertensi. Secara klinis tidak ada perbedaan antara signifikan dari tekanan darah pada laki-laki atau perempuan. Setelah pubertas, pria cenderung memiliki tekanan darah yang lebih tinggi, dan wanita setelah menopause cenderung memiliki tekanan darah yang lebih tinggi dari pada pria pada usia tersebut. (Perry \& Potter, 2005).

Peneliti berasumsi bahwa jenis kelamin mempengaruhi tekanan darah sistolik dan diastolik. Hal ini disebabkan karena masa menapouse pada perempuan yang mengakibatkan penurunan hormon estrogen yang berdampak terhadap peningkatan aktivasi 
dari sistem renin angiotensin dan saraf simpatik yang menyebabkan perubahan dalam mengatur vasokontriksi dan dilatasi dari pembuluh darah sehingga tekanan darah menjadi meningkat. Ini terjadi pada perempuan yang usia nya lebih dari 55 tahun.

\section{Pengaruh Progressive Muscle Relaxation Terhadap Tekanan Darah Sistolik dan Diastolik pada Lansia Hipertensi.}

Kondisi tekanan darah sistolik dan diastolik lansia yang mendapatkan terapi PMR menurun cecara bermakna, bila dibandingkan dengan kelompok kontrol. Hal ini menunjukkan bahwa terapi PMR berpengaru dalam penurunan tekanan darah sistolik dan diastolik pada lansia.

Hasil penelitian ini sesuai dengan teori menurut Ramdhani (2009), mengatakan bahwa relaksasi otot progresif adalah suatu metode untuk membantu menurunkan tegangan sehingga otot tubuh menjadi rileks. Relaksasi otot progresif bertujuan menurunkan kecemasan, stres, otot tegang, kesulitan tidur dan menurunkan tekanan darah. Pada saat tubuh dan pikiran rileks, secara otomatis ketegangan yang seringkali membuat otot-otot mengencang akan diabaikan. Relaksasi otot bertujuan menurunkan sistem saraf simpatis, meningkatkanaktifitas parasimpatis, menurunkan metabolisme, menurunkan tekanan darah dan denyut nadi, serta menurunkan konsumsi oksigen (Perry \& Potter, 2005).

Peneliti berasumsi bahwa pemberian terapi progressive muscle relaxation mempunyai dampak secara langsung terhadap penurunan tekanan darah sistolik dan diastolik pada lansia. Hal ini sesuai dengan hasil analisa penelitian bahwa pemberian terapi progressive muscle relaxation pada kelompok intervensi menunjukkan selisih penurunan yang lebih besar dan berbeda bermakna terhadap penurunan tekanan darah berdasarkan evaluasi diri maupun observasi dari pada kelompok kontrol yang tidak mendapat perlakuan

\section{SIMPULAN}

Berdasarkan hasil penelitian dan uraian pembahasan dapat disimpulkan :

1. Karakteristik lansia dalam penelitian ini hampir seluruh responden adalah perempuan sebanyak 21 (70\%).

2. Kondisi tekanan darah sistolik pada lansia sebelum mendapatkan terapi berada pada tingkat hipertensi derajat 1.

3. Kondisi tekanan darah diastolik pada lansia sebelum mendapatkan terapi berada pada tingkat hipertensi derajat 2

4. Pemberian terapi Progressive Muscle Relaxation menurunkan tekanan darah sistolik dan diastolik secara bermakna dari tingkat hipertensi derajat 1 menjadi tingkat prehipertensi

\section{DAFTAR PUSTAKA}

Amalia, H.N. (2014). Pengaruh Relaksasi Nafas Dalam Terhadap Penurunan Tekanan Darah Pada lbu Hamil Hipertensi Di Puskesmas Kendit Kecamatan Kendit Situbondo. Laporan Penelitian. Situbondo

Black, J.M., \& Hawk, J.H (2005). Medical Surgical Nursing Clinical Management for Positive Aoutcomes. 7th Ed. Philadelphia. Mosbi

BPS (2012). Situasi dan Analisis Lanjut Usia. Survei Sosial Ekonomi Nasional (Susenas) Tahun 2012, Jakarta : BPS

BPS (2014). Statistik Penduduk Lanjut Usia. Survei Sosial Ekonomi Nasional (Susenas) Tahun 2014, Jakarta : BPS

Depkes RI. (2012). Buletin Jendela Data Dan Informasi Kesehatan : Gambaran Kesehatan Lanjut Usia di Indonesia. Jakarta.

(online), (http://www.depkes.go.id/download/Buletin \%20Lansia.pdf, diakses pada tanggal 25 Mei 2018)

Edmund Jacobson. (1980). You Must Relax.London : Unwin Paperbacks.

Harmanto, R (2010). Pengaruh relakasi otot progresif terhadap penurunan tekanan darah klien hipertensi primer di kota malang. Jakarta : Tesis universitas Indonesia

Kaplan, Norman M. (2002). Kaplan's Clinical Hypertension. 8th Ed. Philadelphia : Lippincott Williams \& Wilkis

Potter, P. A \& Perry, A, G. (2005). Fundamental Of Nursing. 5th . Elsevier Mosby. St. Louis, Missouri

Prasetyaningrum Y. Hipertensi bukan untuk ditakuti. Jakarta: Fmedia; 2014

Ramdhani, N, Putra, A.A (2009). Pengembangan Multimedia Relaksasi. http://neila.staff.ugm.ac.id/wordpress/wpc ontent/uploads/2008/05/relaksasi-otot.pdf, diperoleh tanggal 20 Juni 2018

Riset Kesehatan Dasar(Riskesdas). (2013). Badan Penelitian dan Pengembangan Kesehatan Kementerian $R I$ tahun 2013.Diakses: 19 Juni 2018, dari http://www.depkes.go.id/resources/downlo ad/general/Hasil\%20Riskesdas\%202013. pdf

Saryono. (2008). Kumpulan instrument penelitian kesehatan. Yogyakarta: Mulia Medika

Schwickert, J, Lansorst, A, Paul, A,Michalsen, JG, Dobos, (2006). Stres Manajemen dalam pengobatan Hipertensi Arteri Esensial. http//www.ipnoguida.net/2009/02/gestione 
-stress-hipertensione, diperoleh tanggal 20 Juni 2018

Setyoadi.(2011). Terapi Modalitas Keperawatan pada Klien Psikogeriatrik. Salemba Medika: Jakarta

Stuart, G. W. (2016). Prinsip dan Praktik Keperawatan Kesehatan Jiwa Stuart. Buku 1 \& 2. 1st Indonesia edition, by Keliat \& Pasaribu. Elsevier Singapore Pte Ltd.

Sucipto, A., (2014). Pengaruh Teknik Relaksasi Otot Progresif Terhadap Tekanan Darah Pada Lansia Dengan Hipertensi Di Desa Karang bendo Bangun tapan Bantul Yogyakarta. Laporan Penelitian UGM. Susilo, Y. \& Wulandari, A. (2011). Cara jitu mengenal darah tinggi (hipertensi). Yogyakarta: ANDI

Sudoyo A, et al. Buku Ajar Ilmu Penyakit Dalam. Jakarta : FKUI; 2006

Sunardi, (2012). Hidangan Sehat untuk Penderita Hipertensi. Jakarta : Gramedia 